\title{
Gyümölcslé gyártási hulladék komposzt (RAUCH) hatásának vizsgálata karbonátos homoktalajon
}

\author{
KÁDÁR IMRE-DRASKOVITS ESZTER-MORVAI BALÁZS \\ MTA Talajtani és Agrokémiai Kutatóintézet, Budapest
}

\section{Összefoglalás}

Az MTA TAKI Ôrbottyán Kísérleti Telepén, Duna-Tisza közi karbonátos homoktalajon a gyümölcslé gyártási hulladék komposzt hatását tanulmányoztuk szabadföldi terhelési kísérletben. A termőhely talaja erősen meszes, humuszban szegény, P-ral közepesen, $\mathrm{N}$ és K elemekkel igen gyengén ellátott. A terület aszályérzékeny, a talajvíz 5-10 m mélyen található.

A T értéke (CEC) 6-8 mgeé/100 g, agyagtartalom 4-5\%. A kezelések 0, 15, 30, 60, 120 t/ha komposzt sz.a.-nak feleltek meg. Az 5 kezelést 4 ismétlésben és 20 parcellával véletlen blokk elrendezésben állítottuk be 2000 tavaszán. Az első 4 évben Spirit fajtájú rövid tenyészidejű kukoricát, az 5 . évben Disco fajtájú tritikálét termesztettünk. Fơbb megállapításaink:

1. A RAUCH komposzt káros mennyiségben nem tartalmazott nehézfémeket és még a 120 t/ha sz.a. maximális terhelés sem jelentett határérték túllépést.

2. A kukorica termése alacsony maradt ezen a növény számára nem kedvezô termốhelyen 1,3-2,4 t/ha szem, illetve 1,2-2,7 t/ha szár hozamokkal. A trágyázás sem a szem, sem a szár termését nem befolyásolta igazolhatóan, limitáló tényezônek a vízhiány bizonyult. A kísérlet 5 . évében termett tritikále szem termését 1,1-rôl 2,1 t/ha-ra növelte igazolhatóan, de a késôbbi években terméstöbbletek már nem jelentkeztek.

3 . Az alacsony termésekben a makro- és mikroelemek nagyobb része feldúsult, esetenként a normál összetétel 2-3-szorosára a töményedési effektus nyomán. A komposztterheléssel mérséklôdött általában a $\mathrm{Ca}, \mathrm{Mg}$, Sr elemek mennyisége a növényi szervekben, viszont javult a K, P és $\mathrm{Zn}$, ill. részben a Mo és B beépülése.

4. Összességében megállapítható, hogy még az extrém nagy 120 t/ha egyszeri kom- 
poszt adag sem okozott depressziót, sốt az 5. évben terméstöbbleteket eredményezett. A komposzttrágyázással a növényi összetétel kedvezőbbé vált. Az elsô évben végzett talajvizsgálatok adatai szerint a 8 hónap után komposzttal talajba vitt 48 t/ha szervesanyag 30-40\%-át, az összes N 50-60\%-át, míg a P és K mintegy 70\%-át $\mathrm{NH}_{4}$-acetát+EDTA oldható formában találtuk. A maximális komposzt trágyázás nyomán a feltalaj PK-ellátottsága a kielégítő tartományba került.

Kulcsszavak: élelmiszeripari komposzt, tartamkísérlet, karbonátos homoktalaj, talajés növényvizsgálat

\title{
Examining the effect of fruit juice production waste compost (RAUCH) on calcareous sandy soil
}

\author{
I. KÁDÁR-E. DRASKOVITS-B. MORVAI \\ Research Institute for Soil Science and Agricultural Chemistry of the Hungarian \\ Academy of Sciences (RISSAC), Budapest
}

\begin{abstract}
Summary
The effect of fruit juice production waste compost on calcareous sandy soil was examined in the Danube-Tisza mid-region at the Ôrbottyán experiment site of the Research Institute for Soil Science and Agricultural Chemistry of the Hungarian Academy of Sciences by means of a field loading experiment. The soil of the production site is strongly calcareous, weak in humus, averagely supplied with $\mathrm{P}$ and rather weakly supplied with $\mathrm{N}$ and $\mathrm{K}$. The area is drought-sensitive and soil water is at a depth of 5-10 m.

The value of T (CEC) is 6-8 mg equivalent/ $100 \mathrm{~g}$, clay content is $4-5 \%$. The treatments were $0,15,30,60$ and $120 \mathrm{t} \mathrm{ha}^{-1}$ compost dry matter. We established the five treatments in four replications on 20 plots, using a randomised block arrangement in spring 2000. In the first four years, a short growing period maize cultivar called "Spirit", whereas in the fifth year a triticale named "Disco" was grown. Our main observations are as follows:

1. RAUCH compost did not contain a harmful quantity of heavy metals and even the maximum load of $120 \mathrm{t} \mathrm{ha}^{-1}$ dry matter did not exceed the limit values either.

2. The yield of maize remained low (1.3-2.4 $\mathrm{tha}^{-1}$ and 1.2-2.7 $\left.\mathrm{tha}^{-1}\right)$ on this production site which is not favourable for this crop. Fertilisation did not have an effect on
\end{abstract}


grain or stem yield, because water loss was a limiting factor. In the fifth year of the experiment, the grain yield of triticale was increased from $1.1 \mathrm{t} \mathrm{ha}^{-1}$ to $2.1 \mathrm{tha}^{-1}$, but no yield surpluses occured in the following years.

3 . The majority of macro- and microelements became enriched in low yields as a result of concentration effect, sometimes element concentration becoming even 2-3 times higher than the normal composition. Most of the time, the quantity of the elements $\mathrm{Ca}, \mathrm{Mg}$ and Sr decreased in the plant organs as a results of compost loading, whereas the uptake of K, P, Zn and partly Mo and B increased.

4. Altogether, it can be shown that even the extremely high (120 t ha-1) compost dose did not cause depression, it even resulted in yield surpluses in the fifth year. Plant composition became more favourable as a result of compost application. Based on the data of the soil analysis which was carried out after eight months, 30-40\% of the applied organic matter ploughed into the soil with compost was found in soil. The same time, $50-60$ of total $\mathrm{N}$, about $70 \%$ of $\mathrm{P}$ and $\mathrm{K}$ were found in $\mathrm{NH}_{4}$-acetate + EDTA-soluble form. Owing to the maximal compost application, the degree of PK supply of the topsoil became satisfactory.

Key words: compost of fruit juice production, field trial, calcareous sandy soil, soil and plant analysis

\section{Bevezetés és irodalmi áttekintés}

Az ipari folyamatok során nagy mennyiségben keletkeznek hulladékok, melyeket komposztálva trágyaként vagy talajjavító anyagként hasznosíthat a mezőgazdaság. Felhasználásuk azonban nem problémamentes, illetve ellentmondásos. Pozitív hatásként említhetô a talajok szerkezetének, szervesanyag- és tápelemkészletének, biológiai aktivitásának javulása. Kockázatot jelenthet az ilyen trágyaszerek kiegyensúlyozatlan elemösszetétele, a tápelemek egyoldalú talajbani akkumulációja, esetenként a szerves- és ásványi szennyezôk felhalmozódása, patogének terjedése, vízszennyezés (Vetterlein és Hüttl 1996, Seaker és Sopper 1988 a, b; Häni et al. 1996).

Keletkezésükből eredően a hulladék komposztok gazdagok lehetnek N, P, $\mathrm{K}$, valamint a mésztejes és vassókkal végzett stabilizálás miatt Ca és Fe elemekben. A mikroelem készletük nagyságrendekkel különbözhet. Ami a talajfizikai tulajdonságokat illeti, Tester (1990) 0, 60, 120, 240 t/ha sz.a. leszántása 
után 5 évvel tapasztalta a múvelési ellenállás, a kötöttség csökkenését. Martens et al. (1992) 0, 40, 80, 120 t/ha sz.a. komposztot alkalmazott 2 évenkénti leszántással 12 éven át. Eredményei szerint 30\%-kal javult az aggregát stabilitás és nôtt a földigiliszták száma.

Általában kedvezóen alakul a növényborítás, nô a termés. A szervesanyag lebomlása azonban lassú, a komposztok lassú hatású N-forrásnak tekinthetők. Serna és Pomares (1992) közlése szerint pl. 1-2 év után is csak a szervesanyag 5-10\%-a ásványosodott. Más szerzők arra utalnak, hogy bár a szervesanyag mineralizációja lassú, azonban az extrém nagy talajterhelés nyomán jelentôs mérvú $\mathrm{NO}_{3}$-N kilúgzás állhat elô jól szellőzött talajokban. Különösen az elsô években, melyet a talajvizsgálatok is igazolnak. Az ásványi elemek nagyobb része mint a $\mathrm{P}, \mathrm{K}, \mathrm{Ca}$, stb. szintén jól felvehetők lehetnek a növények számára (Boyle és Paul 1989 a, b; Sommer és Marschner 1986, Diez 1982).

Varanka et al. (1976) Chicago város iszapjával végeztek tartamkísérletet 6 éven át. Ezalatt összesen 0, 92, 184, 369 t/ha sz.a. leszántására került sor kukorica monokultúrában. A kezelt talajban megkétszereződött az összes C és N, valamint több mint négyszeresére nőtt a $\mathrm{P}$ készlete és számos nehézfém mennyisége. A bevitt szervesanyag közel fele bomlott el, a visszamaradó szervesanyag frakciókban ugyanakkor többszörösére nôtt a biológiai lebomlásnak ellenállóbb zsírok, gyanták és olajok aránya. A mikroba populáció összetétele és aktivitása azonban érdemben nem változott.

Pomares-Garcia és Pratt (1978) a hagyományos istállótrágyát és az ipari/városi szennyvíziszap komposztot hasonlította össze mint N-forrást. Az istállótrágya pH-ja 8,7; a N\%-a 1,53; C/N aránya 13; $\left(\mathrm{NO}_{3}+\mathrm{NH}_{4}\right)-\mathrm{N}$ tartalma $27 \mathrm{mg} / \mathrm{kg}$; P 0,23\%; K 0,97\%; Ca 0,83\%; Mg 0,34\%; Na 0,17\%; S 0,23\%; Cl 0,67\%; Mn 169 $\mathrm{mg} / \mathrm{kg}$, Fe 0,36\%; Zn 57 mg/kg, Cu 8 mg/kg mennyiséget tett ki. Ezzel szemben az iszapkomposzt $6,0 \mathrm{pH} ; 4,16 \% \mathrm{~N} ; 8 \mathrm{C} / \mathrm{N}$ arány; $1535 \mathrm{mg} / \mathrm{kg}\left(\mathrm{NO}_{3}+\mathrm{NH}_{4}\right)-\mathrm{N}$; 1,28\% P; 0,10\% K; 1,35\% Ca; 0,38\% Fe; 866 mg/kg Zn és 486 mg/kg Cu összetételt mutatott. Az iszap komposzt rendkívül gazdagnak bizonyult összes és ásványi N-ben szúk $\mathrm{C} / \mathrm{N}$ aránnyal, valamint $\mathrm{P}, \mathrm{Ca}, \mathrm{Zn}$ és $\mathrm{Cu}$ elemekben. Tenyészedény kísérletben 2,5 hónap után az istállótrágyának kereken 4\%-a, míg az iszapkomposztnak 17\%-a ásványosodott.

Munkánk célja volt a kevéssé ismert gyümölcslé gyártási hulladék komposzt (RAUCH) hatásának vizsgálata szabadföldi tartamkísérletben, Duna-Tisza közi homoktalajon. Ugyanezen a termőhelyen vágóhídi hulladék komposzttal is tartamkísérleteket folytatunk (ATEV komposzt). Eredményeink szerint a vá- 
góhídi komposzttrágya 60 vagy 120 t/ha sz.a. egyszeri dózisban is alkalmazható, hatása több évig tart és a talaj termékenységét előnyösen befolyásolja ezen a tápanyagokban és szervesanyagban szegény karbonátos homokon (Ragályi és Kádár 2007, 2008). Különbözô talajokkal beállított tenyészedény kísérletekben a bốrgyári és a kommunális szennyvíziszapok talajra és növényre gyakorolt hatását szintén elemeztük. Tapasztalataink szerint az iszapkomposztokkal bevitt szervesanyag a talajban még 3 év után is jól kimutatható, tehát nem bomlik el (Kádár és Morvai 2007, 2008).

\section{Anyag és módszer}

A termôhely a Duna-Tisza közi homokhátság északi részén, a gödöllói dombvidék pereméhez közel helyezkedik el. A kísérleti terület a homoktalajokhoz hasonlóan rossz vízgazdálkodású, aszályérzékeny és heterogén. A talajvíz tükre 10 m mélyen található, a talajképződési folyamatokat, illetve a trágyahatásokat nem befolyásolja. A feltalaj is erôsen meszes, humuszban szegény, az AL-oldható P-tartalma alapján közepesen, míg K-készlete alapján igen gyengén ellátott. A T értéke 6-8 mgeé/100 g, agyagtartalma 4-5\%, kötöttsége $\mathrm{K}_{\mathrm{A}}=25$. A $\mathrm{CaCO}_{3}$ 8-9\% (3,2-3,6\% Ca), melynek mintegy 60\%-át AL-oldható formában lehet kimutatni az 1. táblázatban közölt adatok szerint.

1. táblázat. A kísérlet talajának alapvizsgálati jellemzói a 0-20 és $20-40 \mathrm{~cm}$ rétegben

(Karbonátos homoktalaj, Duna-Tisza köze, Örbottyán)

\begin{tabular}{|c|c|c|c|c|c|c|c|}
\hline \multirow{2}{*}{$\begin{array}{l}\text { Mintavétel } \\
\text { mélysége, cm } \\
\text { (1) }\end{array}$} & \multicolumn{2}{|c|}{$\mathrm{pH}$} & \multirow{2}{*}{$\begin{array}{c}\mathrm{CaCO}_{3} \\
\%\end{array}$} & \multirow{2}{*}{$\begin{array}{c}\text { Humusz } \\
\% \\
(2) \\
\end{array}$} & \multirow{2}{*}{$\begin{array}{c}\text { AL-Ca } \\
\%\end{array}$} & \multicolumn{2}{|c|}{ AL- $\mathrm{P}_{2} \mathrm{O}_{5} \quad$ AL- $\mathrm{K}_{2} \mathrm{O}$} \\
\hline & $\mathrm{H}_{2} \mathrm{O}$ & $\mathrm{KCl}$ & & & & \multicolumn{2}{|c|}{$\mathrm{mg} / \mathrm{kg}$} \\
\hline $0-20$ & 7,8 & 7,4 & 7,8 & 0,8 & 2,0 & 123 & 66 \\
\hline $20-40$ & 7,9 & 7,5 & 9,3 & 0,6 & 2,2 & 97 & 52 \\
\hline
\end{tabular}

Megjegyzés: Kötöttség $\mathrm{K}_{\mathrm{A}}$ 25, agyagtartalom 4-5\%, kation adszorpció (T érték) 6-8 mgeé/100 g Table 1. The basic analysis features of the experiment soil in the layers of 0-20 and 20-40 cm depths (Calcareous sandy soil, Danube-Tisza mid-region, Ốrbottyán). (1) Sampling depth, cm, (2) Humus \%. Note: Plasticity: $\mathrm{K}_{\mathrm{A}} 25$, clay content: $4-5 \%$, cation adsorption (T value): 6-8 mg equivalent/100 $\mathrm{g}$.

A kísérletet 5 kezeléssel és 4 ismétlésben, azaz 20 parcellában állítottuk be. A parcellák $5 \times 8=40 \mathrm{~m}^{2}$ területet jelentettek véletlen blokk elrendezésben. A 
kezelések 0, 15, 30, 60 és 120 t/ha komposzt sz.a.-nak feleltek meg. A 60\% nedvességtartalmú komposztot 2000. március 10-én szórtuk ki kézzel az egyes parcellákra és még azon a napon leszántottuk. A csemegekukorica vetésére május 29-én került sor $70 \times 20 \mathrm{~cm}$ kötésben kézi vetőpuskával. A rövid tenyészidejú Spirit fajtájú kukorica vetése 2001 és 2002 években április közepe táján, a kézi törés augusztus végén történt. Nettó területként a parcellák belsô $4-4$ sora szolgált.

A 2003. évben értékelhető termést nem kaptunk. A kukorica 5 hónapos tenyészideje alatt mindössze $122 \mathrm{~mm}$ csapadék hullott. A homok termóhelyek nem igazán alkalmasak a kukorica termesztésére. A 2004. évben Disco fajtájú tritikálet termesztettünk 3-5 cm mélyre vetve $240 \mathrm{~kg} /$ ha vetőmagnormával. A vetés 2003. szeptember végén, a betakarítás 2004. július 20-án történt. A kukorica kísérletben betakarításkor parcellánként 20-20 tövet vettünk mintakéveként analízis céljából 2000-ben és 2001-ben. A 2001. évben ezen túlmenôen a virágzás kezdetén 20-20 cső alatti levelet is begyújtöttünk elemzésre. A tritikálekísérletben 8-8 fm = 1-1 $\mathrm{m}^{2}$ föld feletti anyag szolgált a szem és a szalma elemzésére parcellánként. A kísérletben végzett agrotechnikai múveletekrôl és megfigyelésekrôl a 2. táblázat nyújt áttekintést.

A növénymintákat $40-50{ }^{\circ} \mathrm{C}$-on történt szárítást követôen finomra ôröltük, majd cc. $\mathrm{HNO}_{3}+\mathrm{cc} . \mathrm{H}_{2} \mathrm{O}_{2}$ roncsolás után meghatároztuk elemtartalmukat ICP technikát alkalmazva. A $\mathrm{N}$ mérése cc. $\mathrm{H}_{2} \mathrm{SO}_{4}+$ cc. $\mathrm{H}_{2} \mathrm{O}_{2}$ feltárást követôen történt az ISO 11261 (1995) szabvány szerint a módosított Kjeldahl (1891) módszerrel. A talajok alapvizsgálati jellemzőit Baranyai et al. (1987), illetve MÉM NAK (1978) által ismertetett eljárásokkal vizsgáltuk. Az ammóniumlaktát + ecetsav oldható PK tartalmakat Egnér et al. (1960), a humuszt Tyurin (1937) által ajánlottak szerint határoztuk meg. Az elsô év végén, a kukorica betakarítását követően parcellánként átlagmintákat vettünk 20-20 lefúrás anyagát egyesítve a szántott rétegből. A mintákban vizsgáltuk a humusz és az összes $\mathrm{N}$ mennyiségét, valamint az $\mathrm{NH}_{4}$-acetát+EDTA oldható elemtartalmakat Lakanen és Erviö (1971) által ajánlott módszerrel.

Ami a csapadékviszonyokat illeti, az alábbiakra utalunk. A kukorica 5 hónapos tenyészideje alatt 2000-ben összesen $150 \mathrm{~mm}$ eső hullott. Aszályos volt a május $15 \mathrm{~mm}$, a június $7 \mathrm{~mm}$ és az augusztus $8 \mathrm{~mm}$ hozammal. 2001-ben ezzel ellentétben szokatlanul csapadékos volt az április 170 mm, a május 115 mm és a július $117 \mathrm{~mm}$ vízhozammal. A 2002. év csapadékszegény volt, míg az extrém aszály miatt 2003-ban a kukorica teljesen elszáradt és kipusztult már júniusban. 


\section{2. táblázat. Agrotechnikai múveletek és megfigyelések a kisérletben (Karbonátos homoktalaj, Duna-Tisza köze, Órbottyán)}

\begin{tabular}{|c|c|c|}
\hline $\begin{array}{c}\text { Müveletek és megfigyelések } \\
(1)\end{array}$ & $\begin{array}{c}\text { Év, hó, nap } \\
\text { (2) }\end{array}$ & $\begin{array}{c}\text { Megjegyzés } \\
\text { (3) }\end{array}$ \\
\hline 1. Komposzt kiszórása (4) & 2000.03 .10 . & Parcellánként kézzel (22) \\
\hline 2. Komposzt leszántása (5) & 2000.03 .10 & MTZ-50+eke (23) \\
\hline 3. Kukorica vetése $(70 \times 20 \mathrm{~cm})(6)$ & 2000.05 .29 . & Kézi vetőpuskával (24) \\
\hline 4. Sorközmüvelés (7) & 2000.08 .01 & Parcellánként kézzel (22) \\
\hline 5. Betakarítás, mintavétel (8) & 2000.09 .18 & 20 tő/parcella, kézzel (25) \\
\hline 6. Öszi szántás, kultivátorozás (9) & 2000.11 .06$. & MTZ-50+eke+kultivátor (26) \\
\hline 7. Talajmintavétel $(0-20 \mathrm{~cm})(10)$ & 2000.11 .06$. & 20 lefúrás/nettó parcella (27) \\
\hline 1. Kombinátorozás (11) & 2001.04 .09$. & MTZ-50+kultivátor (28) \\
\hline 2. Kukorica vetése $(70 \times 20 \mathrm{~cm})(6)$ & 2001.04 .18$. & Kézi vetőpuskával (24) \\
\hline 3. Sorközmüvelés, kapálás (12) & 2001.05 .16 & Kézi kapálás (29) \\
\hline 4. Levélmintavétel (13) & 2001.07 .16 & 20-20 db/parcella, cső alatti (30) \\
\hline 5. Növénymintavétel (14) & 2001.08 .31 & 20-20 tö/parcella (31) \\
\hline 6. Betakarítás (15) & 2001.08 .31 & 4-4 belső sor/parcella (32) \\
\hline 7. Öszi szántás, kombinátorozás (16) & 2001.10 .10$. & MTZ-50+eke+kombinátor (33) \\
\hline 1. Kukorica vetése (6) & 2002.04 .16$. & Kézi vetőpuskával (24) \\
\hline 2. Kapálás, gyomírtás (17) & 2002.05 .28 & Kézzel parcellánként (22) \\
\hline 3. Minta kéve vétele (18) & 2002.08 .27$. & 20-20 tö/parcella (31) \\
\hline 4. Betakarítás (15) & 2002.08 .27$. & 4-4 belső sor/parcella (32) \\
\hline 5. Öszi szántás, kombinátorozás (16) & 2002.10 .04$. & MTZ-50+eke+kombinátor (33) \\
\hline 1. Öszi elmunkálás (19) & 2003.09 .30 & MTZ-50+kombinátor (34) \\
\hline 2. Tritikále vetése, hengerezés (20) & 2003.09 .30 & MTZ-50+vetőgép+henger (35) \\
\hline 3. Bonitálás állományra (21) & 2004. 05. 24 . & Parcellánként virágzásban (36) \\
\hline 4. Bonitálás állományra (21) & 2004.07. 19 . & Aratás előtt parcellánként (37) \\
\hline 5. Mintavétel, betakarítás (8) & 2004.07.20. & $8-8 \mathrm{fm}=1-1 \mathrm{~m}^{2} /$ parcella $(38)$ \\
\hline
\end{tabular}

Megjegyzés: Spirit csemegekukorica fajta kb. 100 napos tenyészidôvel. Vetés mélysége $5 \mathrm{~cm}, 70 \times 20$ kötésben, $30 \mathrm{~kg} /$ ha vetômaggal. A tritikále Disco fajta, 3-5 cm mélyre vetve $240 \mathrm{~kg} /$ ha vetômaggal. Table 2. Agrotechnical operations and observations in the experiment (Calcareous sandy soil, Danube-Tisza mid-region, Ôrbottyán). (1) Operations and observations, (2) Year, month, day, (3) Note, (4) Spreading compost, (5) Ploughing compost into the soil, (6) Sowing maize $(70 \times 20 \mathrm{~cm})$, (7) Inter-row cultivation, (8) Harvesting, sampling, (9) Autumn ploughing, using cultivator, (10) Soil sampling (0-20 cm), (11) Using combinator, (12) Inter-row cultivation, hoeing, (13) Leaf sampling, (14) Plant sampling, (15) Harvest, (16) Autumn ploughing, using combinator, (17) Hoeing, weed control, (18) Taking a sample sheaf, (19) Finishing the soil in the autumn, (20) Sowing triticale, using roller, (21) Evaluating the plant population, (22) Manually per plot, (23) MTZ-50 + plough, (24) Using a hand-held seeder, (25) 20 crops/plot, manually, (26) MTZ-50 + plough + cultivator, (27) 20 drills/net plot, (28) MTZ-50 + cultivator, (29) Manual hoeing, (30) 20-20 pcs/plot, below the cob, (31) 20-20 corps/plot, (32) 4-4 inner row/plot, (33) MTZ-50 + plough + combinator, (34) MTZ-50 + combinator, (35) MTZ-50 + sowing machine + roller, (36) During flowering per plot, (37) Before harvest per plot, (38) 8-8 running meters $=1-1 \mathrm{~m}^{2}$ per plot. Note: Sweet corn: Spirit cultivar with 100 days long growing period. Sowing depth: $5 \mathrm{~cm}$ with a binding of $70 \times 20$ and $30 \mathrm{~kg} \mathrm{ha}^{-1}$ sowing seeds. Triticale: Disco cultivar, $3-5 \mathrm{~cm}$ sowing depth, $240 \mathrm{~kg} \mathrm{ha}^{-1}$ sowing seeds 
Az 5. növényként vetett tritikále 9 hónapos tenyészideje alatt, 2003 októbere és 2004 júniusa között, összesen 428 mm csapadékot kapott többé-kevésbé egyenletes eloszlásban (3. táblázat).

3. táblázat. A kukorica tenyészideje alatt lehullott havi csapadékösszegek 2000. és 2004. között, $m m$

(Karbonátos homoktalaj, Duna-Tisza köze, Órbottyán)

\begin{tabular}{ccccccc}
\hline $\begin{array}{c}\text { Évek } \\
(1)\end{array}$ & $\begin{array}{c}\text { Április } \\
(2)\end{array}$ & $\begin{array}{c}\text { Május } \\
(3)\end{array}$ & $\begin{array}{c}\text { Június } \\
(4)\end{array}$ & $\begin{array}{c}\text { Július } \\
(5)\end{array}$ & $\begin{array}{c}\text { Augusztus } \\
(6)\end{array}$ & $\begin{array}{c}\text { Összesen } \\
(7)\end{array}$ \\
\hline & & & & & & \\
2000. & 49 & 15 & 7 & 71 & 8 & 150 \\
2001. & 170 & 115 & 48 & 117 & 19 & 469 \\
2002. & 30 & 46 & 41 & 52 & 98 & 267 \\
2003. & 12 & 32 & 8 & 57 & 13 & 122 \\
2004. & 39 & 42 & 68 & 35 & 67 & 251 \\
\hline
\end{tabular}

Megjegyzés: A tritikále aktív 9 hónapos tenyészideje alatt 428 mm csapadékot kapott (2003. októbere és 2004. júniusa között).

Table 3. The monthly precipitation sums during the growing period of maize between 2000 and 2004, mm (Calcareous sandy soil, Danube-Tisza mid-region, Ốrbottyán). (1) Years, (2) April, (3) May, (4) June, (5) July, (6) August, (7) Total. Note: There was $428 \mathrm{~mm}$ precipitation during the active nine months long growing period of triticale (between October 2003 and June 2004).

\section{Kísérleti eredmények}

A RAUCH komposzt az alábbi jellemzókkel rendelkezett: pH 6,1; izzítási veszteség 40-45\%; C/N arány 18-23; $\mathrm{NH}_{4}-\mathrm{N} 385 \mathrm{mg} / \mathrm{kg} ; \mathrm{NO}_{3}-\mathrm{N} 74 \mathrm{mg} / \mathrm{kg}$; humuszminôség Q=0,268, AL- $\mathrm{K}_{2} \mathrm{O} 0,20 \% ; \mathrm{AL}-\mathrm{P}_{2} \mathrm{O}_{5}$ 0,07\% a szárazanyagban. Hargitai (1988) szerint a 0,5\%-os $\mathrm{NaOH}$ oldatban fóként az átalakuló nyers szervesanyagok oldódnak. A jó minőségú nagymolekulájú Ca-hoz kötött szervesanyagot módszere szerint az 1\%-os NaF oldat extrahálja. A NaF/NaOH extrakciók aránya adja a $Q$ humuszstabilitási számot, utalhat a humuszminóségre. A RAUCH komposzt tehát nyers, még nem humifikált szervesanyagból áll. Az össz-N tartalmát tekintve szegény, kicsi a $\mathrm{NO}_{3}-\mathrm{N}$, illetve nagy az $\mathrm{NH}_{4}-\mathrm{N}$ készlete. A C/N aránya viszonylag tág, lassú hatású $\mathrm{N}$-trágyának minősülhet a kiszórását követô években (4. táblázat).

A komposzt összes K-tartalma 0,36\%-ot tett ki, a P-tartalom 0,22\%-nak adódott. A K-készletnek mintegy 50\%-a, míg az összes P-tartalomnak 14\%-a ammóni- 
umlaktát-ecetsav (AL) módszerrel kioldható volt. Amint a 4. táblázat adataiból látható, a RAUCH komposzt nem tartalmaz káros mennyiségben nehézfémeket, így termőföldön szervestrágyaként felhasználható a 40/2008. (II. 26.) kormányrendeletben engedélyezett szennyezettségi határértékek alapján. Sôt, még a 120 t/ha sz.a. komposzt maximális adagja sem okozott olyan talajterhelést, mely a rendeletben kijuttatható $\mathrm{kg} / \mathrm{ha}$ /év mennyiségeket meghaladta volna. A hivatkozott rendelet 5 . sz. melléklete szerint ugyanis termóföldön az elemterhelés határértéke az alábbi lehet, ha/év: Cr(III), Pb és Cu $10 \mathrm{~kg}$; Ni 2 kg; Se $1 \mathrm{~kg}$; As és Co 0,5 kg; Mo 0,2 kg; Cd 0,15 kg, Hg 0,1 kg.

A N-terhelés maximuma számításaink alapján az $1560 \mathrm{~kg} / \mathrm{ha}$-t is elérte, de ez nem érinti a 49/2001. (IV.3.) korm. rendeletben elôírt mennyiségi korlátozást. Utóbbi szerint „Mezógazdasági területre éves szinten szerves trágyával kijuttatott nitrogén mennyisége nem haladhatja meg a $170 \mathrm{~kg} / \mathrm{ha}$ értéket, beleértve a legeltetés során az állatok által kijuttatott, továbbá a szennyvizekkel és szennyvíziszapokkal kijuttatott mennyiséget is." A rendelet ugyanis a szervestrágya fogalmát az alábbiakban rögzíti: „Az állatállomány által ürített trágya, illetve a trágya és az alom keveréke, feldolgozott formában is, idetartozik különösen a hígtrágya, az istállótrágya."

Említésre méltó viszont az $1440 \mathrm{~kg} / \mathrm{ha}$-t elérô Ca-terhelés, mely 3,6 t/ha $\mathrm{CaCO}_{3}$ egyenértéket képviselhet, tehát egy közepes meszezést jelenthetne savanyú talajon. A maximális PK-terhelés, a becsült oldhatóságát is figyelembe véve, több év mérsékelt gabonatermés PK-igényét kielégíthetné. A mikroelemek általi terhelés elhanyagolhatónak túnik a Fe, Al, Mn kivételével. Utóbbiak azonban jellegzetes talajalkotók, így a talaj összes készletéhez viszonyítva elenyészô mennyiséget tehetnek csak ki (4. táblázat).

A komposzttrágya igazolhatóan nem módosította a kukorica alacsony termését a kísérlet elsô 3 évében. A szemtermések az évek átlagában 1,3-2,4 t/ha, a szártermések 1,2-2,7 t/ha, az összes földfeletti biomassza hozama 2,8-5,5 t/ha között ingadozott ezen a kukorica számára nem kedvezố termóhelyen. A 4. évben 2003-ban értékelhetố kukoricatermést nem kaptunk. A kísérlet 5. évében a tritikále szem és szalma termése igazolhatóan közel kétszeresére emelkedett a maximális komposzttrágya adagjával. A további években a tritikále monokultúra azonban már trágyahatásokat nem mutatott (5. táblázat).

A légszáraz kukorica szem és szár termésének átlagos elemtartalmát a 6 . táblázatban tanulmányozhatjuk. Az aszályos 2000. évben a töményedési effektus érvényesült, a kis termésben az ásványi elemek extrém módon feldúsultak. 
4. táblázat. Gyümölcslégyártási hulladék komposzt (RAUCH) átlagos összetétele és az általa okozott talajterhelés

\begin{tabular}{|c|c|c|c|c|c|c|c|}
\hline \multirow{2}{*}{$\begin{array}{l}\text { Elem } \\
\text { jele } \\
(1)\end{array}$} & \multirow{2}{*}{$\begin{array}{l}\text { Mérték- } \\
\text { egység } \\
\text { (2) }\end{array}$} & \multirow{2}{*}{$\begin{array}{l}\text { Komposzt } \\
\text { sz.a.-ban } \\
\text { (3) }\end{array}$} & \multicolumn{5}{|c|}{$\begin{array}{l}\text { Komposzt trágyázás sz.a. t/ha 2000-ben } \\
\text { (4) }\end{array}$} \\
\hline & & & 0 & 15 & 30 & 60 & 120 \\
\hline \multicolumn{8}{|c|}{ Elemterhelés kg/ha (5) } \\
\hline $\mathrm{N}$ & $\%$ & 1,30 & 0 & 195 & 390 & 780 & 1560 \\
\hline $\mathrm{Ca}$ & $\%$ & 1,20 & 0 & 180 & 360 & 720 & 1440 \\
\hline $\mathrm{Fe}$ & $\%$ & 0,50 & 0 & 75 & 150 & 300 & 600 \\
\hline $\mathrm{Al}$ & $\%$ & 0,39 & 0 & 58 & 117 & 234 & 468 \\
\hline $\mathrm{K}$ & $\%$ & 0,36 & 0 & 54 & 108 & 216 & 432 \\
\hline $\mathrm{Mg}$ & $\%$ & 0,28 & 0 & 42 & 84 & 168 & 336 \\
\hline $\mathrm{P}$ & $\%$ & 0,22 & 0 & 33 & 66 & 132 & 264 \\
\hline $\mathrm{Mn}$ & $\mathrm{mg} / \mathrm{kg}$ & 140 & 0 & 2,10 & 4,20 & 8,40 & 16,80 \\
\hline $\mathrm{Cr}$ & $\mathrm{mg} / \mathrm{kg}$ & 50 & 0 & 0,75 & 1,50 & 3,00 & 6,00 \\
\hline $\mathrm{Na}$ & $\mathrm{mg} / \mathrm{kg}$ & 40 & 0 & 0,60 & 1,20 & 2,40 & 4,80 \\
\hline $\mathrm{Ba}$ & $\mathrm{mg} / \mathrm{kg}$ & 28 & 0 & 0,42 & 0,84 & 1,68 & 3,36 \\
\hline $\mathrm{Zn}$ & $\mathrm{mg} / \mathrm{kg}$ & 28 & 0 & 0,42 & 0,84 & 1,68 & 3,36 \\
\hline $\mathrm{Sr}$ & $\mathrm{mg} / \mathrm{kg}$ & 23 & 0 & 0,34 & 0,69 & 1,38 & 2,76 \\
\hline $\mathrm{Cu}$ & $\mathrm{mg} / \mathrm{kg}$ & 13 & 0 & 0,20 & 0,39 & 0,78 & 1,56 \\
\hline $\mathrm{Ni}$ & $\mathrm{mg} / \mathrm{kg}$ & 13 & 0 & 0,20 & 0,39 & 0,78 & 1,56 \\
\hline B & $\mathrm{mg} / \mathrm{kg}$ & 11 & 0 & 0,16 & 0,33 & 0,66 & 1,32 \\
\hline \multicolumn{8}{|c|}{ Elemterhelés g/ha (6) } \\
\hline $\mathrm{Pb}$ & $\mathrm{mg} / \mathrm{kg}$ & 4,5 & 0 & 68 & 135 & 270 & 540 \\
\hline Co & $\mathrm{mg} / \mathrm{kg}$ & 3,6 & 0 & 54 & 108 & 216 & 432 \\
\hline As & $\mathrm{mg} / \mathrm{kg}$ & 1,3 & 0 & 20 & 39 & 78 & 156 \\
\hline Mo & $\mathrm{mg} / \mathrm{kg}$ & 0,6 & 0 & 9 & 18 & 36 & 72 \\
\hline $\mathrm{Cd}$ & $\mathrm{mg} / \mathrm{kg}$ & 0,1 & 0 & 1,5 & 3 & 6 & 12 \\
\hline $\mathrm{Se}$ & $\mathrm{mg} / \mathrm{kg}$ & 0,08 & 0 & 1,2 & 2,4 & 4,8 & 9,6 \\
\hline
\end{tabular}

Megjegyzés: pH 6,2; izzítási veszteség 41\%; $\mathrm{C} / \mathrm{N}$ arány 32; $\mathrm{AL}-\mathrm{K}_{2} \mathrm{O} 0,20 \%$; $\mathrm{AL}-\mathrm{P}_{2} \mathrm{O}_{5} 0,07 \%$; $\mathrm{NH}_{4} \mathrm{~N}$ $385 \mathrm{mg} / \mathrm{kg} ; \mathrm{NO}_{3}-\mathrm{N} 74 \mathrm{mg} / \mathrm{kg}$; humuszminóség $\mathrm{Q}=0,268 ;$ sz.a. $60 \%$

Table 4 . The average composition of fruit juice production waste compost (RAUCH) and the soil load caused by it. (1) Element symbol, (2) Measurement unit, (3) Compost expressed in dry matter, (4) Compost application, dry matter that in 2000, (5) Element loading, $\mathrm{kg} \mathrm{ha}^{-1}$, (6) Element loading, $\mathrm{g} \mathrm{ha}^{-1}$. Note: $\mathrm{pH}$ : 6.2; ignation's loss: $41 \%$; $\mathrm{C} / \mathrm{N}$ ratio: $32 ; \mathrm{AL}-\mathrm{K}_{2} \mathrm{O}: 0.20 \% ; \mathrm{AL}_{2} \mathrm{P}_{2} \mathrm{O}_{5}: 0.07 \% ; \mathrm{NH}_{4}-\mathrm{N}: 385$ $\mathrm{mg} \mathrm{kg}{ }^{-1} ; \mathrm{NO}_{3}-\mathrm{N}: 74 \mathrm{mg} \mathrm{kg}{ }^{-1} ;$ quality of humus: $\mathrm{Q}=0.268$; dry matter: $60 \%$.

A szemben és a szárban a N, P, Mg, S, Ca makroelemek mennyisége megközelítően kétszerese, míg a mikroelemek mennyisége 2-3-szorosa a mészlepedékes csernozjom talajon termett kukorica összetételéhez viszonyítva. Az említett 
csernozjom talajon 7 t/ha szem és 8 t/ha körüli szár termett 1993-ban, egy szárazabb évjáratban (Kádár 2004). A 2001. évben drasztikusan lecsökkent a legtöbb makro- és mikroelem mennyisége a növényi szövetekben 2000. évhez képest. A túl bô csapadékkal a talajbani oldható formák felhígultak, kilúgzódhattak, a talajoldat betöményedése és így a növényi extrém akkumuláció elmaradt. Legalábbis a szemtermésben, amikor az esôs hónapokat követôen augusztusban mindössze $19 \mathrm{~mm}$ csapadék hullott.

\section{5. táblázat. Gyümölcslégyártási hulladék komposzt (RAUCH) hatása a kísérleti} növények aratáskori légszáraz termésére, $t / h a$ (Karbonátos homoktalaj, Duna-Tisza köze, Ôrbottyán)

\begin{tabular}{|c|c|c|c|c|c|c|c|}
\hline \multirow{2}{*}{$\begin{array}{l}\text { Növényi } \\
\text { rész } \\
(1)\end{array}$} & \multicolumn{7}{|c|}{$\begin{array}{l}\text { Komposzt trágyázás sz.a. t/ha 2000-ben } \\
\text { (2) }\end{array}$} \\
\hline & 0 & 15 & 30 & 60 & 120 & $\begin{array}{c}\mathrm{SzD}_{5 \%} \\
(3)\end{array}$ & $\begin{array}{l}\text { Átlag } \\
(4)\end{array}$ \\
\hline \multicolumn{8}{|c|}{ Csemege kukorica (Spirit) 2000-ben (5) } \\
\hline Szem (6) & 1,9 & 2,0 & 2,2 & 2,2 & 2,5 & 0,6 & 2,2 \\
\hline Szár (7) & 2,3 & 2,4 & 2,8 & 2,8 & 3,0 & 0,9 & 2,7 \\
\hline Összes* (8) & 4,8 & 5,1 & 5,7 & 5,7 & 6,2 & 1,5 & 5,5 \\
\hline \multicolumn{8}{|c|}{ Csemege kukorica (Spirit) 2001-ben (9) } \\
\hline Szem (6) & 2,4 & 2,4 & 2,3 & 2,3 & 2,6 & 0,5 & 2,4 \\
\hline Szár (7) & 1,8 & 1,8 & 1,9 & 1,9 & 2,2 & 0,5 & 1,9 \\
\hline Összes* (8) & 4,7 & 4,7 & 4,7 & 4,6 & 5,2 & 1,0 & 4,8 \\
\hline \multicolumn{8}{|c|}{ Csemege kukorica (Spirit) 2002-ben (10) } \\
\hline Szem (6) & 1,2 & 1,3 & 1,2 & 1,4 & 1,4 & 0,4 & 1,3 \\
\hline Szár (7) & 1,1 & 1,1 & 1,2 & 1,4 & 1,3 & 0,3 & 1,2 \\
\hline Összes* (8) & 2,6 & 2,6 & 2,7 & 3,1 & 3,1 & 0,5 & 2,8 \\
\hline \multicolumn{8}{|c|}{ Tritikále (Disco) 2004-ben (11) } \\
\hline Szem (6) & 1,1 & 1,3 & 1,7 & 1,7 & 2,1 & 0,4 & 1,6 \\
\hline Szár (7) & 1,6 & 2,0 & 2,4 & 2,4 & 3,0 & 0,5 & 2,3 \\
\hline Összes* (8) & 3,1 & 3,8 & 4,7 & 4,6 & 5,6 & 1,2 & 4,3 \\
\hline
\end{tabular}

Megjegyzés: 2003-ban értékelhetó kukoricatermést nem kaptunk. *Összes a csutka, illetve pelyva terméssel együtt számolva.

Table 5. The effect of fruit juice production waste compost (RAUCH) on the air-dry yield of experimental crops during harvest, $\mathrm{t} \mathrm{ha}^{-1}$ (Calcareous sandy soil, Danube-Tisza mid-region, Ốrbottyán). (1) Plant organ, (2) Compost application, dry matter tha-1 in 2000, (3) $\mathrm{LSD}_{5 \%}$, (4) Average, (5) Sweet corn (Spirit) in 2000, (6) Grain, (7) Stem, (8) Total*, (9) Sweet corn (Spirit) in 2001, (10) Sweet corn (Spirit) in 2002, (11) Triticale (Disco) in 2004. Note: We did not get considerable maize yield in 2003. *Also considering cob and chaff. 
A szártermés összetétele más képet mutat. Csak a N-tartalom jelzi egyértelmúen a hígulást. A szártermés rendkívül kicsi, mindössze 1,9 t/ha volt átlagosan és mind a makro-, mind a mikroelem összetételét tekintve a 2000. évhez hasonlóan töményedési effektust jelez (6. táblázat).

6. táblázat. A légszáraz kukorica szem, szár és a virágzáskori csöalatti levél átlagos elemtartalma

(Karbonátos homoktalaj, Duna-Tisza köze, Ôrbottyán)

\begin{tabular}{|c|c|c|c|c|c|c|}
\hline \multirow{2}{*}{$\begin{array}{l}\text { Elem } \\
\text { jele } \\
(1)\end{array}$} & \multirow{2}{*}{$\begin{array}{l}\text { Mérték- } \\
\text { egység } \\
\text { (2) }\end{array}$} & \multicolumn{2}{|c|}{$\begin{array}{c}\text { Szemtermés } \\
\text { (3) }\end{array}$} & \multicolumn{2}{|c|}{$\begin{array}{c}\text { Szártermés } \\
\text { (4) }\end{array}$} & \multirow{2}{*}{$\begin{array}{c}\begin{array}{c}\text { Levél } \\
(5)\end{array} \\
\text { 2001-ben } \\
\text { (7) }\end{array}$} \\
\hline & & $\begin{array}{c}\text { 2000-ben } \\
\text { (6) }\end{array}$ & $\begin{array}{l}\text { 2001-ben } \\
\text { (7) }\end{array}$ & $\begin{array}{c}\text { 2000-ben } \\
\text { (6) }\end{array}$ & $\begin{array}{c}\text { 2001-ben } \\
\text { (7) }\end{array}$ & \\
\hline $\mathrm{N}$ & $\%$ & 2,78 & 1,94 & 1,77 & 1,20 & 1,62 \\
\hline K & $\%$ & 1,09 & 0,60 & 1,40 & 1,59 & 1,09 \\
\hline $\mathrm{P}$ & $\%$ & 0,71 & 0,38 & 0,25 & 0,38 & 0,30 \\
\hline $\mathrm{Mg}$ & $\%$ & 0,25 & 0,15 & 0,42 & 0,40 & 0,87 \\
\hline $\mathrm{S}$ & $\%$ & 0,21 & 0,15 & 0,19 & 0,20 & 0,25 \\
\hline $\mathrm{Ca}$ & $\%$ & 0,02 & 0,01 & 1,07 & 0,95 & 2,18 \\
\hline $\mathrm{Fe}$ & $\mathrm{mg} / \mathrm{kg}$ & 57 & 27 & * & $*$ & $*$ \\
\hline $\mathrm{Zn}$ & $\mathrm{mg} / \mathrm{kg}$ & 51 & 28 & 22 & 28 & 11 \\
\hline $\mathrm{Mn}$ & $\mathrm{mg} / \mathrm{kg}$ & 19 & 9 & 136 & 111 & 160 \\
\hline $\mathrm{Na}$ & $\mathrm{mg} / \mathrm{kg}$ & 8 & 8 & 18 & 29 & 36 \\
\hline $\mathrm{Cu}$ & $\mathrm{mg} / \mathrm{kg}$ & 4 & 2 & 8 & 6 & 9 \\
\hline $\mathrm{Al}$ & $\mathrm{mg} / \mathrm{kg}$ & 7 & 2 & * & $*$ & * \\
\hline B & $\mathrm{mg} / \mathrm{kg}$ & 4 & 2 & 10 & 12 & 11 \\
\hline $\mathrm{Sr}$ & $\mathrm{mg} / \mathrm{kg}$ & 0,9 & 0,4 & 33 & 30 & 62 \\
\hline Mo & $\mathrm{mg} / \mathrm{kg}$ & 0,4 & 0,3 & 0,3 & 1,3 & 2,3 \\
\hline $\mathrm{Ba}$ & $\mathrm{mg} / \mathrm{kg}$ & 0,2 & $<0,1$ & 9,7 & 7,6 & 8,0 \\
\hline $\mathrm{Cr}$ & $\mathrm{mg} / \mathrm{kg}$ & 0,2 & 0,2 & 2,0 & 1,4 & 1,7 \\
\hline $\mathrm{Ni}$ & $\mathrm{mg} / \mathrm{kg}$ & 0,2 & 0,6 & 1,8 & 1,5 & 1,4 \\
\hline Co & $\mathrm{mg} / \mathrm{kg}$ & 0,04 & 0,01 & 0,68 & 0,42 & 0,60 \\
\hline $\mathrm{Cd}$ & $\mathrm{mg} / \mathrm{kg}$ & 0,01 & 0,01 & 0,10 & 0,08 & 0,10 \\
\hline
\end{tabular}

Megjegyzés: Az As 0,06 mg/kg; Hg 0,5 mg/kg; Se 0,3 mg/kg; Pb 0,2 mg/kg méréshatár alatt. *A szár, levél $1000 \mathrm{mg} / \mathrm{kg}$ körüli Fe és Al koncentrációkat mutatott feltehetôen a porszennyezésból eredốn, közlésüktốl ezért eltekintünk.

Table 6. Average element content of the air-dry grain, stem and leaf below the cob during flowering (Calcareous sandy soil, Danube-Tisza mid-region, Őrbottyán). (1) Element symbol, (2) Measurement unit, (3) Grain yield, (4) Stem yield, (5) Leaf, (6) in 2000, (7) in 2001. Note: As: $0.06 \mathrm{mg} \mathrm{kg}^{-1}$; Hg: 0.5 mg kg ; Se: $0.3 \mathrm{mg} \mathrm{kg}^{-1} ; \mathrm{Pb}: 0.2 \mathrm{mg} \mathrm{kg}^{-1}$ under measurement limit. *The stem and leaf showed $\mathrm{Fe}$ and Al concentrations around $1000 \mathrm{mg} \mathrm{kg}^{-1}$, probably due to dust pollution, therefore we forbear from publishing them. 
A bemutatott adatokból az is látható, hogy a N, P és részben a Zn kivételével az ásványi elemek döntôen a melléktermésben, a szárban akkumulálódnak. Az As $0,6 \mathrm{mg} / \mathrm{kg}, \mathrm{Hg} 0,5 \mathrm{mg} / \mathrm{kg}$, Se $0,3 \mathrm{mg} / \mathrm{kg}$ és az $\mathrm{Pb} 0,2 \mathrm{mg} / \mathrm{kg}$ méréshatár alatt maradt mind a szemben, mind a szárban. Megemlítjük, hogy a fajlagos, azaz 1 t szem + hozzá tartozó melléktermés elemtartalmának becslésétôl eltekintettünk. Szaktanácsadási szempontból félrevezető lehet a tápelemigény-számítás a hasonló viszonyok között, mert túlbecslést eredményezhet. Száraz évben a mútrágyák egyébként sem hasznosulhatnak, utóhatásukkal viszont számolhatunk a következô növény trágyaigényének megítélése során.

Amennyiben a 2001-ben vett virágzáskori csőalatti levél és a szár átlagos összetételét vetjük össze megállapítható, hogy a fiatal levél gazdagabb N, Mg, S, Ca, Sr, Fe, Mn, Al, Mo elemekben. Kiugrónak minősülhet a levél Ca és Sr akkumulációja. Szegényebbnek bizonyult ugyanakkor K, P, Zn, Cu elemeket tekintve. Bergmann (1992) szerint a virágzáskori csőalatti levél a növény optimális tápláltsági állapotát tükrözheti, ha a N 2,8-3,5\%, K 2,0-3,5\%, Ca 0,25-1,00\%, P 0,250,50\%, Mg 0,20-0,50\%, Mn 35-100 mg/kg, Zn 25-70 mg/kg, B 6-15 mg/kg, Cu 6-12 mg/kg, Mo 0,15-0,50 mg/kg a szárazanyagban. Diagnosztikai szempontból vizsgálva arra a következtetésre juthatunk, hogy a virágzás kezdetén a kukorica a N, K és Zn elemek hiányát, valamint a Ca, Mg, Mn, Mo elemek erốteljes túlsúlyát jelezte (6. táblázat). A komposzt terhelés módosította néhány elem összetételét a kukorica légszáraz szerveiben. Mindkét vizsgált évben mérsékelte a szem Ca és Sr, valamint növelte igazolhatóan a Mo és 2001-ben a Zn tartalmát is. A szártermésben mindkét évben látványosan emelkedett a K és Mo mennyisége, 2001-ben a P és a Zn dúsulása is bizonyítható volt. Mindkét évben visszaesett a Mg és a Sr beépülése a komposzttrágyázással. A virágzáskori csőalatti levél szintén jelezte a Mg és a Sr felvételének gátlását, illetve a K, P, Zn és a B elemek fokozott akkumulációját. Összességében megállapítható, hogy a komposzttrágyázással a kukorica szerveinek összetétele kedvezô irányban módosult ( 7 . táblázat). Annak ellenére, hogy a maximális Ca-terhelés elérte az $1440 \mathrm{~kg} / \mathrm{ha}$ mennyiséget ezen a sülevényes karbonátos termőhelyen, a komposzttrágya óriási szervesanyag készletével ellensúlyozni tudta a Ca-túlsúly kedvezőtlen hatását. Sajnos az aszályos évek negatív hatását azonban nem, a kukorica nem jelezte a kedvezôbb vízgazdálkodás tényét. További vizsgálatok szükségesek annak megállapítására, hogy a talajba vitt mintegy 48 t/ha szervesanyag mennyiben mutatható ki talajvizsgálatokkal, illetve mekkora részaránya bomlott el az évek során. Elvileg ez a mennyiség a 3000 t/ha szántott réteg 1,5\%-át képviselheti. 
7. táblázat. Gyümölcslégyártási hulladék komposzt (RAUCH) hatása a kukorica légszáraz szerveinek elemösszetételére

(Karbonátos homoktalaj, Duna-Tisza köze, Örbottyán)

\begin{tabular}{|c|c|c|c|c|c|c|c|c|}
\hline \multirow{2}{*}{$\begin{array}{l}\text { Elem } \\
\text { jele } \\
(1)\end{array}$} & \multirow{2}{*}{$\begin{array}{c}\text { Mérték- } \\
\text { egység } \\
\text { (2) }\end{array}$} & \multicolumn{7}{|c|}{$\begin{array}{c}\text { Komposzt trágyázás sz. a. t/ha 2000-ben } \\
\text { (3) }\end{array}$} \\
\hline & & 0 & 15 & 30 & 60 & 120 & $\begin{array}{c}\mathrm{SzD}_{5 \%} \\
(4)\end{array}$ & $\begin{array}{l}\text { Átlag } \\
(5)\end{array}$ \\
\hline \multicolumn{9}{|c|}{ Szem 2000-ben (6) } \\
\hline $\mathrm{Ca}$ & $\mathrm{mg} / \mathrm{kg}$ & 283 & 248 & 235 & 238 & 213 & 54 & 243 \\
\hline $\mathrm{Sr}$ & $\mathrm{mg} / \mathrm{kg}$ & 1,34 & 0,88 & 0,81 & 0,85 & 0,72 & 0,45 & 0,92 \\
\hline Mo & $\mathrm{mg} / \mathrm{kg}$ & 0,31 & 0,35 & 0,39 & 0,43 & 0,39 & 0,08 & 0,37 \\
\hline \multicolumn{9}{|c|}{ Szem 2001-ben (7) } \\
\hline $\mathrm{Ca}$ & $\mathrm{mg} / \mathrm{kg}$ & 143 & 113 & 115 & 95 & 108 & 28 & 115 \\
\hline $\mathrm{Zn}$ & $\mathrm{mg} / \mathrm{kg}$ & 25 & 26 & 26 & 28 & 34 & 5 & 28 \\
\hline $\mathrm{Sr}$ & $\mathrm{mg} / \mathrm{kg}$ & 0,51 & 0,37 & 0,39 & 0,32 & 0,35 & 0,13 & 0,39 \\
\hline Mo & $\mathrm{mg} / \mathrm{kg}$ & 0,27 & 0,30 & 0,32 & 0,39 & 0,44 & 0,09 & 0,34 \\
\hline \multicolumn{9}{|c|}{ Szár 2000-ben (8) } \\
\hline $\mathrm{K}$ & $\%$ & 0,84 & 1,20 & 1,39 & 1,57 & 1,97 & 0,35 & 1,40 \\
\hline $\mathrm{Mg}$ & $\%$ & 0,49 & 0,42 & 0,40 & 0,40 & 0,37 & 0,05 & 0,42 \\
\hline $\mathrm{Sr}$ & $\mathrm{mg} / \mathrm{kg}$ & 39 & 32 & 32 & 32 & 31 & 10 & 33 \\
\hline $\mathrm{Zn}$ & $\mathrm{mg} / \mathrm{kg}$ & 26 & 25 & 20 & 20 & 19 & 7 & 22 \\
\hline $\mathrm{Cu}$ & $\mathrm{mg} / \mathrm{kg}$ & 9,21 & 8,17 & 8,42 & 8,81 & 7,68 & 1,30 & 8,46 \\
\hline Mo & $\mathrm{mg} / \mathrm{kg}$ & 0,22 & 0,29 & 0,33 & 0,37 & 0,33 & 0,05 & 0,34 \\
\hline \multicolumn{9}{|c|}{ Szár 2001-ben (9) } \\
\hline $\mathrm{K}$ & $\%$ & 1,16 & 1,64 & 1,44 & 1,69 & 2,02 & 0,41 & 1,59 \\
\hline $\mathrm{Mg}$ & $\%$ & 0,48 & 0,40 & 0,39 & 0,38 & 0,37 & 0,11 & 0,40 \\
\hline $\mathrm{P}$ & $\%$ & 0,30 & 0,35 & 0,34 & 0,41 & 0,50 & 0,10 & 0,38 \\
\hline $\mathrm{Sr}$ & $\mathrm{mg} / \mathrm{kg}$ & 38 & 28 & 28 & 28 & 25 & 12 & 30 \\
\hline $\mathrm{Zn}$ & $\mathrm{mg} / \mathrm{kg}$ & 20 & 24 & 26 & 30 & 38 & 7 & 28 \\
\hline Mo & $\mathrm{mg} / \mathrm{kg}$ & 0,84 & 1,00 & 1,03 & 1,58 & 2,07 & 0,52 & 1,30 \\
\hline \multicolumn{9}{|c|}{ Cső alatti levél virágzás elején 2001-ben (10) } \\
\hline $\mathrm{Mg}$ & $\%$ & 1,03 & 0,90 & 0,85 & 0,79 & 0,78 & 0,17 & 0,87 \\
\hline $\mathrm{K}$ & $\%$ & 0,62 & 0,89 & 1,09 & 1,27 & 1,60 & 0,46 & 1,09 \\
\hline $\mathrm{P}$ & $\%$ & 0,21 & 0,23 & 0,28 & 0,34 & 0,46 & 0,10 & 0,30 \\
\hline $\mathrm{Sr}$ & $\mathrm{mg} / \mathrm{kg}$ & 71 & 64 & 64 & 58 & 55 & 24 & 62 \\
\hline $\mathrm{Zn}$ & $\mathrm{mg} / \mathrm{kg}$ & 9 & 9 & 8 & 12 & 15 & 6 & 11 \\
\hline $\mathrm{B}$ & $\mathrm{mg} / \mathrm{kg}$ & 8 & 10 & 11 & 11 & 13 & 3 & 11 \\
\hline Mo & $\mathrm{mg} / \mathrm{kg}$ & 1,21 & 1,72 & 2,14 & 2,62 & 3,64 & 0,66 & 2,27 \\
\hline
\end{tabular}

Table 7 . The effect of fruit juice production waste compost (RAUCH) on the element composition of the air-dry organs of maize (Calcareous sandy soil, Danube-Tisza mid-region, Ôrbottyán). (1) Element symbol, (2) Measurement unit, (3) Compost application, dry matter $\mathrm{tha}^{-1}$ in 2000, (4) LSD $_{5 \%}$, (5) Average, (6) Grain in 2000, (7) Grain in 2001, (8) Stem in 2000, (9) Stem in 2001, (10) Leaf below the cob in the beginning of the flowering period in 2001. 
A 8. táblázatban közölt eredmények szerint a kontroll talaj 0,90\% körüli humusztartalma 1,42\%-ra emelkedett a maximális 120 t/ha szárazanyagterhelés nyomán. Az izzítási veszteséget alapul véve 40-50 t/ha szervesanyag bevitele történt, tehát a komposzttal talajba juttatott szervesanyag mintegy 30-40\%-át találtuk a szántott rétegben 8 hónap után.

8. táblázat. RAUCH komposzt hatása a talaj szántott rétegének összetételére 8 hónap után, 2000. november 6-án (Duna-Tisza közi meszes homoktalaj, Ôrbottyán)

\begin{tabular}{|c|c|c|c|c|c|c|c|c|}
\hline \multirow{2}{*}{$\begin{array}{l}\text { Vizsgált } \\
\text { jellemző } \\
\text { (1) }\end{array}$} & \multirow{2}{*}{$\begin{array}{c}\text { Mérték- } \\
\text { egység } \\
\text { (2) }\end{array}$} & \multicolumn{7}{|c|}{$\begin{array}{l}\text { Komposzt trágyázás sz. a. t/ha 2000-ben } \\
\text { (3) }\end{array}$} \\
\hline & & 0 & 15 & 30 & 60 & 120 & $\begin{array}{c}\mathrm{SzD}_{5 \%} \\
(4)\end{array}$ & $\begin{array}{c}\text { Átlag } \\
(5)\end{array}$ \\
\hline Humusz (6) & $\%$ & 0,90 & 0,92 & 0,98 & 1,15 & 1,42 & 0,29 & 1,08 \\
\hline Össz-N (7) & $\mathrm{mg} / \mathrm{kg}$ & 600 & 640 & 640 & 790 & 900 & 180 & 710 \\
\hline \multicolumn{9}{|c|}{$\mathrm{NH}_{4}$-acetát+EDTA oldható* (8) } \\
\hline $\mathrm{Ca}$ & $\%$ & 1,75 & 1,48 & 1,48 & 1,70 & 1,24 & 0,79 & 1,53 \\
\hline $\mathrm{P}_{2} \mathrm{O}_{5}$ & $\mathrm{mg} / \mathrm{kg}$ & 104 & 100 & 110 & 132 & 179 & 56 & 125 \\
\hline $\mathrm{K}_{2} \mathrm{O}$ & $\mathrm{mg} / \mathrm{kg}$ & 50 & 61 & 66 & 84 & 152 & 53 & 83 \\
\hline $\mathrm{B}$ & $\mathrm{mg} / \mathrm{kg}$ & 0,4 & 0,4 & 0,4 & 0,5 & 0,6 & 0,1 & 0,5 \\
\hline
\end{tabular}

*Megjegyzés: Mg 496; Mn 111; Sr 26; Na 12; Ba 9; Zn és Cu 2; Pb és Ni 1 mg/kg körül átlagosan a kezeléstôl függetlenül. As, Cd, Mo, Se oldható mennyisége $0,1 \mathrm{mg} / \mathrm{kg}$ kimutatási határ alatt. Table 8. The effect RAUCH compost on the composition of the ploughed layer of soil after eight months on 6 November (Calcareous sandy soil, Danube-Tisza mid-region, Ôrbottyán). (1) Examined feature, (2) Measurement unit, (3) Compost application, dry matter tha' ${ }^{-1}$ in 2000 , (4) $\mathrm{LSD}_{5 \%}$, (5) Average, (6) Humus, (7) Total N, (8) $\mathrm{NH}_{4}$-acetate + EDTA-soluble*. *Note: Mg: 496; Mn: 111; Sr: 26; $\mathrm{Na}: 12$; $\mathrm{Ba}: 9 ; \mathrm{Zn}$ and $\mathrm{Cu}: 2$; $\mathrm{Pb}$ and $\mathrm{Ni}: 1 \mathrm{mg} \mathrm{kg}^{-1}$ (average values independently of treatments). The soluble quantity of As, Cd, Mo and Se is below the detection limit of $0.1 \mathrm{mg} \mathrm{kg}^{-1}$.

A humusszal párhuzamosan a talaj össz-N készlete is igazolhatóan mintegy $50 \%-k a l$ nőtt. Elméletileg az $1560 \mathrm{~kg} / \mathrm{ha} \mathrm{N}$-bevitel $520 \mathrm{mg} / \mathrm{kg}$ növekményt indukálhat a 3 millió $\mathrm{kg} / \mathrm{ha}$ szántott réteg talajában. A $300 \mathrm{mg} / \mathrm{kg}$ kontrollhoz viszonyított össz-N akkumuláció arra utal, hogy a bevitt $\mathrm{N}$ nagyobb része, vagy jó fele, még a szántott rétegben maradt feltehetôen szerves formában. Bár a komposzttal becsléseink szerint közel $500 \mathrm{mg} / \mathrm{kg} \mathrm{Ca}$ is beszántásra került, ez a mennyiség elenyészó a heterogén homoktalaj Ca-tartalmához viszonyítva. A talaj 
$\mathrm{NH}_{4}$-acetát+EDTA oldható Ca-készlete $15300 \mathrm{mg} / \mathrm{kg}$-nak adódott átlagosan, a kísérleti hiba $7900 \mathrm{mg} / \mathrm{kg}$ volt. Az sem ismert valójában, hogy a komposzt Cakészletének milyen lehetett az $\mathrm{NH}_{4}$-acetát+EDTA oldható részaránya. Hasonló mondható el a Mg talajbani kimutathatóságát illetôen, valamint a Fe és Al elemek tekintetében, melyek érdemi talajalkotók. A kezeléstôl függetlenül a Mg 496, Mn 111, Sr 26, Na 12, Ba 9, Zn és a Cu 2, Pb és a Ni 1 mg/kg körüli átlagos koncentrációt ért el. A Co $0,7 \mathrm{mg} / \mathrm{kg}$, míg az As, Cd, Mo, Se oldható tartalma 0,1 $\mathrm{mg} / \mathrm{kg}$ kimutatási határ alatt maradt. A talaj oldható P-tartalma maximálisan 75 $\mathrm{mg} / \mathrm{kg}$, míg a K-tartalom $102 \mathrm{mg} / \mathrm{kg}$ mennyiséggel nôtt meg és ezzel a talaj P- és K-ellátottsága a kielégítố tartományba kerülhetett a korábbi határértékvizsgálataink szerint (Kádár 1992, 2006, Csathó 1997). A bemutatott adatok arra utalnak, hogy a komposzttal a talajba vitt P és K mintegy 70\%-a NH 4 -acetát+EDTA oldható formában maradt a bevitel helyén, míg a B 10-20\%-a volt azonosítható (8. táblázat).

\section{Köszönetnyilvánítás}

A munka a 49042 és 68665 sz. OTKA, valamint a CRO-13/2006 sz. pályázat eredményeként az NKTH és a KPI támogatásával jött létre, mely támogatás forrása a Kutatási és Technológiai Innovációs Alap.

\section{IRODALOM}

Baranyai F.-Fekete A.-Kovács I.: 1987. A magyarországi talaj tápanyagvizsgálatok eredményei. Mezógazdasági Kiadó. Budapest.

Bergmann, W.: 1992. Nutritional Disorders of Plants. Gustav Fischer Verlag. JenaStuttgart-New-York.

Boyle, M.-Paul, E. A.: 1989a. Carbon and nitrogen mineralization kinetics in soil previously amended with sewage sludge. Soil Sci. Am. J. 53: 99-103.

Boyle, M.-Paul, E. A.: 1989b. Nitrogen transformation in soil previously amended with sewage sludge. Soil Sci. Am. J. 53: 740-744.

Csathó P.: 1997. Összefüggés a talaj K-ellátottsága és a kukorica, ôszi búza és a lucerna K-hatások között hazai szabadföldi kísérletekben, 1960-1990. Agrokémia és Talajtan. 46: 327-346.

Diez, Th.: 1982. Landwirtschaftliche Klärschlammverwertung in Ballungsräumen, dargestellt am Beispiel der Stadt München. Z. f. Kulturtechnik und Flurbereinigung. 23: 149-163. 
Egnér, H.-Riehm, H.-Domingo, W. R.: 1960. Untersuchungen über die chemische Bodenanalyse als Grundlage für die Beurteilung des Nährstoffzustandes der Böden. II. K. Lantbr. Högsk. Ann. 26: 199-215.

Hargitai L.: 1988. A talaj szervesanyagának meghatározása és jellemzése. [In: Buzás I. (szerk.) Talaj- és agrokémiai vizsgálati módszerkönyv 2.] Mezőgazdasági Kiadó. Budapest. 151-173.

Häni, H.-Sigenthaler, A.-Candinas, T.: 1966. Soil effects due to sewage sludge application in agriculture. Fertilizer Research. 43: 149-156.

ISO 11261: 1995. Soil Quality. Determination of total nitrogen. Modified Kjeldahl method.

Kádár I.: 1992. A növénytáplálás alapelvei és módszerei. MTA TAKI. Budapest.

Kádár I.: 2004. A mútrágyázás hatása a silókukorica termésére karbonátos csernozjom talajon. Növénytermelés. 53. 3: 285-297.

Kádár I.: 2006. Növény-és talajvizsgálatok értelmezése mútrágyázási tartamkísérletben. Növénytermelés: 55. 2: 123-137.

Kádár I.-Morvai B.: 2007. Ipari-kommunális szennyvíziszap-terhelés hatásának vizsgálata tenyészedény-kísérletben. Agrokémia és Talajtan. 56: 333-352.

Kádár I.-Morvai B.: 2008. Bôrgyári szennyvíziszap vizsgálata tenyészedény kísérletben. A Ca, Na és Cr elemek forgalma. Növénytermelés. 57. 1: 35-48.

Kjeldahl, J.: 1891. Neue Methode zur Bestimmung des Stickstoffs in organischen Körpern. Zeitschr. f. analyt. Chemie. 22: 366-382.

Lakanen, E.-Erviö, R.: 1971. A comparison of eight extractants for the determination of plant available microelements in soils. Acta Agr. Fenn. 123: 223-232.

40/2008. (II. 26.) Korm. rendelet a szennyvizek és szennyvíziszapok mezőgazdasági felhasználásának és kezelésének szabályairól szóló 50/2001. (IV. 3.) Korm. rendelet módosításáról. Magyar Közlöny. 2008. 31: 1316-1327.

49/2001. (IV. 3.) Korm. rendelete a vizek mezógazdasági eredetú nitrátszennyezéssel szembeni védelméről. Magyar Közlöny. 2001. 39: 2518-2531.

Martens, D. A.-Johanson, J. B.-Frankenberger, W. T.: 1992. Production and persistence of soil enzymes with repeated addition of organic residues. Soil Sci. 153: 53-61.

MÉM NAK: 1978. A TVG tápanyagvizsgáló laboratórium módszerfüzete. MÉM Növényvédelmi és Agrokémiai Központ. Budapest. 48.

Pomares-Garcia, F.-Pratt, P. F.: 1978. Value of manure and sewage sludge as $\mathrm{N}$ fertilizer. Agronomy J. 70: 1065-1069.

Ragályi, P.-Kádár, I.: 2007. Composted slanghterhouse by-products effect on crop yield. [In: Láng et al. (eds.) Joint Int. Conference on Long-tem Experiments, Agric. Research and Natural Resources.] Univ. of Debrecen, Hungary and Univ. of Oradea, Romania. 239-246.

Ragályi, P.-Kádár, I.: 2008. Processed slaughterhouse waste application on calcareous sandy soil. Acta Agron. Óváriensis. 50. 1: 95-101.

Seaker, E. M.-Sopper, W. E.: 1988a. Municipal sewage sludge for minespoil reclamation. Effects on microbial populations and activity. J. Environ. Qual. 17: 591-597. 
Seaker, E. M.-Sopper, W. E.: 1988b. Municipal sewage sludge for minespoil reclamation.

II. Effects on organic matter. J. Environ. Qual. 17: 598-602.

Serna, M. D.-Pomares, F.: 1992. Indexes of assessing $\mathrm{N}$ availability in sewage sludge. Plant and Soil. 139: 15-21.

Sommer, B.-Marschner, H.: 1986. Pflanzenverfügtbarkeit vor Schwermetallen aus Böden. Eugen Ulmer GmbH and Co. Stuttgart.

Tester, C. F.: 1990. Organic amendment effects on physical and chemical properties of a sandy soil. Soil Sci. Soc. Am. J. 54: 827-831.

Tyurin, I. V.: 1937. Organicseszkie vescsesztva pocsv. Szelhozgiz. Moszkva.

Varanka, W. M.-Zablocki, M. Z.-Hinesly, D.: 1976. The effect of digested sludge on soil biological activity. J. Water Poll. Contr. 1728-1740.

Vetterlein, D.-Hüttl, R. F.: 1996. Aspects of soil conservation in respect to the application of recycled plant nutrients from industrial processes. [In: Schnug and Szabolcs (eds.) $10^{\text {th }}$ Intern. Symp. of CIEC.] Braunschweig. 51-78.

A szerzôk levelezési címe - Address of the authors:

Dr. Kádár Imre-Draskovits Eszter-Morvai Balázs

MTA Talajtani és Agrokémiai Kutatóintézet

Budapest

Herman O. u. 15.

H-1022 